\title{
ETIKA LINGKUNGAN SISWA SEKOLAH DASAR DI PEKANBARU
}

\author{
Nur Salwa, Eddy Noviana \\ nursalwatriokta@gmai.com, eddy.noviana@lecturer.unri.ac.id, \\ Program Studi Pendidikan Guru Sekolah Dasar \\ Universitas Riau, Indonesia
}

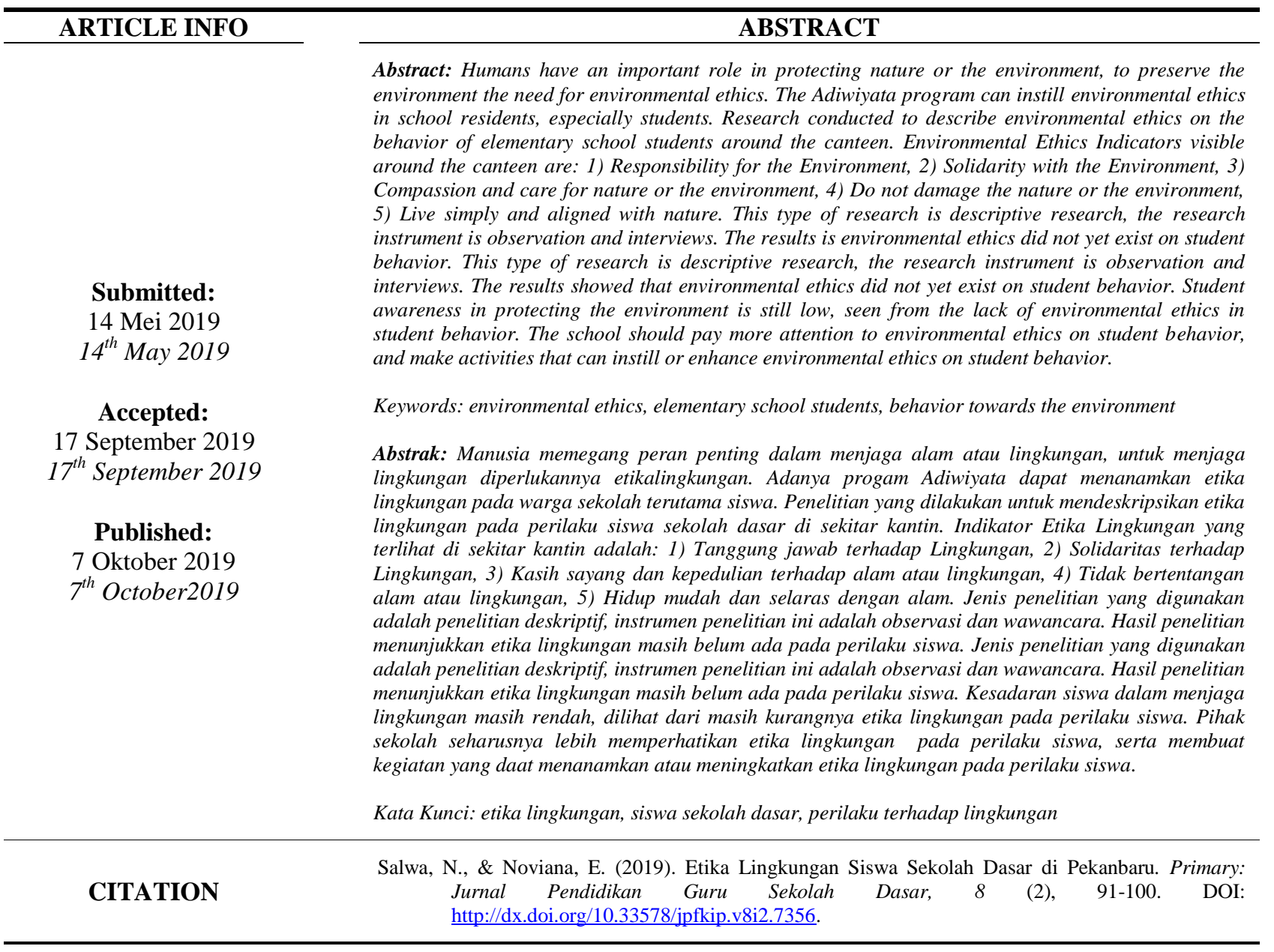

\section{PENDAHULUAN}

Sekolah merupakan salah satu tempat untuk siswa belajar akan pentingnya menjaga lingkungan, adanya program Adiwiyata di sekolah adalah upaya pemerintah dalam menumbuhkan kesadaran siswa terhadap lingkungan. Siswa sekolah dasar seharusnya sudah tahu akan tentang pentingnya menjaga lingkungan, salah satu cara untuk menjaga lingkungan adalah dengan selalu memperhatikan setiap tindakan atau perilaku terhadap lingkungan. Aturan-aturan yang mengatur bagaimana seharusnya terhadap lingkungan disebut dengan etika lingkungan, oleh karena itu 
diperlukannya etika lingkungan dalam berperilaku terhadap lingkungan. Etika lingkungan adalah salah satu faktor instrinsik yang mempengaruhi perilaku manusia terhadap lingkungan (Frey, 1992), yang merupakan dasar manusia dalam pengambilan keputusan berdasarkan prinsipprinsip dan aturan yang merupakan hasil dari akal atau pikiran manusia (Suliantoro, 2011). Etika lingkungan dapat diperoleh melalui program adiwiyata, karena adiwiyata merupakan tempat yang baik dan ideal untuk memperoleh segala ilmu pengetahuan dan berbagai norma serta etika yang dapat menjadi dasar manusia menuju terciptanya kesejahteraan hidup (Tim Adiwiyata, 2012).

Etika lingkungan adalah aturan-aturan atau norma tentang bagaimana seharusnya perilaku manusia dalam berhubungan dengan alam serta nilai dan prinsip-prinsip yang yang menjadi pedoman manusia dalam berperilaku terhadap alam atau lingkungan (Keraf, 2010). Etika lingkungan pada manusia yaitu kebijaksanaan moral manusia dalam bertindak atau berperilaku terhadap lingkungan, yang mana setiap kegiatannya selalu dipertimbangkan dengan cermat dan bijak sehingga keseimbangan lingkungan tetap terjaga (Febrita, 2017), yaitu bagaimana manusai memilih tindakan yang baik dan bijak sebelum bertindak atau berperilaku terhadaplingkungan (Florit \& Grava, 2017; Jennings, Yun, \& Larson, 2016). Etika lingkungan dapat dilihat dari pelaksanaan prinsip-prinsipnya. Ada sembilan prinsip etika lingkungan yaitu: prinsip hormat terhadap alam, prinsip tanggung jawab, prinsip solidaritas kosmis, prinsip kasih sayang dan kepedulian terhadap alam, prinsip tidak merugikan alam, prinsip hidup sederhana dan selaras dengan alam, prinsip keadilan, prinsip demokrasi dan prinsip integritas moral (Keraf, 2010). Etika

\section{METODE PENELITIAN}

Jenis penelitian yang digunakan dalam penelitian ini adalah penelitian deskriptif. Penelitian deskriptif ditujukan untuk menggambarkan fenomena-fenomena yang ada, yang berlangsung saat ini atau saat yang lampau. Penelitian ini tidak mengadakan manipulasi atau pengubahan pada variabel-variabel bebas, tetapi menggambarkan suatu kondisi apa adanya lingkungan mempunyai peran dalam terbentuknya sikap yang peduli teradap lingkungan. Hal tersebut telah dibuktikan dalam penelitian Eko Ariwododo yang meneliti tentang relevansi pengetahuan masyarakat tentang lingkungan dan etika lingkungan dengan partisipasinya dalam pelestarian lingkungan, hasilnya menunjukkan bahwa adanya relevansi antara pengetahuan lingkungan hidup dan etika lingkungan secara bersama sama terhadap partisipasi anggota masyarakat dalam pelestarian lingkungan (Ariwidodo, 2014). Penelitian tentang perilaku lingkungan telah diteliti sebelumnya, yaitu meneliti tentang perilaku pelajar tingkat menengah terhadap lingkungan di Kabupaten Bogor. Dari penelitian yang dilakukan, didapatkan hasil bahwa yang paling mempengaruhi perilaku lingkungan adalah norma subjektif. Hal ini selaras dengan teori etika lingkungan (Barkatin, Syaufina, \& Wijiyanto, 2016).

Penulis melakukan pengamatan terhadap salah satu sekolah dasar adiwiyata di Pekanbaru, warga sekolah yang sudah mendapat penghargaan adiwiyata tentunya sudah memiliki etika lingkungan dalam berperilaku terhadap lingkungan terutama di lingkungan sekolah. Namun dari pengamatan yang dilakukan, penulis melihat masih banyaknya siswa yang tidak peduli terhadap kebersihan lingkungan terutama di sekitar kantin. Penulis melihat masih banyaknya sampah yang berserakan, dan sikap siswa yang acuh terhadap sampah tersebut.

Berdasarkan permasalahan tersebut, peneliti melakuan penelitian yang bertujuan untuk melihat dan mendeskripsikan etika lingkungan yang ada pada perilaku siswa pada sekolah yang mendapat penghargaan adiwiyata, dengan melihat perilaku siswa disekitar kantin.

(Sukmadinata, 2015). Penelitian dilakukan di salah satu sekolah dasar berpredikat adiwiyata di Pekanbaru, sebelum melakukan penelitian peneliti telah melakukan survei terlebih dahulu pada Oktober 2018. Penelitian dimulai dari 14 Januari09 Februari 2019, observasi dilakukan sebanyak dua belas. Peneliti mengobservasi tindakan atau perilaku siswa kelas tinggi terhadap lingkungan 
sekolah terutama kantin untuk menemukan etika lingkungan yang belum atau sudah ada pada tindakan atau perilaku siswa tersebut. Observasi dilakukan dari 14 Januari-02 Februari.

Subjek dalam penelitian ini adalah siswa kelas tinggi (IV, V dan VI). Instrumen utama dalam penelitian ini adalah observasi, peneliti melakukan observasi pada perilaku siswa. Etika lingkungan pada perilaku siswa diukur dengan indikator etika lingkungan yang diambil dari prinsip-prinsip etika lingkungan. Adapun indikator yang dapat dilihat pada perilaku siswa di sekitar kantin yaitu : 1) Tanggung jawab terhadap

\section{HASIL DAN PEMBAHASAN}

Melalui observasi dan wawacara peneliti mendapatkan data tentang perilaku atau tindakan siswa terhadap lingkungan sekolah, etika lingkungan secara keseluruhan masih kurang pada perilaku siswa. Berikut pemaparan hasil penelitian setiap indikator:

\section{a. Tanggung Jawab terhadap Lingkungan}

Aspek yang menggambarkan tanggung jawab terhadap lingkungan yaitu membuang sampah pada tong sampah dan mengajak teman untuk menjaga kebersihan lingkungan seperti mengutip sampah yang berserakan Persentase indikator tanggung jawab yang ada pada peilaku siswa hanya $50 \%$, karena dari 2 aspek yang menggambarkan tanggung jawab terhadap lingkungan tersebut hanya satu yang terlihat pada perilaku siswa. Siswa sudah sering membuang sampah pada tong sampah, namun masih jarang untuk mengajak temannya dalam menjaga kebersihan lingkungan. Siswa telah memiliki tanggung jawab terhadap sampah yang dimilikinya, namun tanggung jawab siswa terhadap kebersihan lingkungan masih belum terlihat.

Pada observasi ke-1 ada lima orang siswa yang membuang sampah pada tong sampah, pada observasi ke-2 ada satu orang siswa yang membuang sampah pada tong sampah, pada observasi ke-3 ada dua orang siswa yang membuang sampah pada tong sampah, pada observasi ke-4 ada satu orang siswa yang membuang sampah pada tong sampah, pada lingkungan, 2) Solidaritas terhadap lingkungan, 3) Kasih sayang dan kepedulian terhadap alam atau lingkungan, 4) Tidak merusak alam atau lingkungan, 5) Hidup sederhana dan selaras dengan alam (Keraf, 2010). Untuk melengkapi data observasi peneliti melakukan wawacara kepada siswa, responden ditentukan secara random dengan mengambil 10\% dari jumlah subjek karena jumlah subjek lebih dari 100 (Riduwan, 2012).

Data yang telah diperoleh, dianalisis berdasarkan indikator etika lingkungan yang kemudian dideskripsikan dengan bantuan diagram dan tabel.

observasi ke-5 ada dua orang siswa yang membuang sampah pada tong sampah, pada observasi ke-6 ada satu orang siswa yang membuang sampah pada tong sampah, pada observasike-7 ada tiga orang siswa yang membuang sampah pada tong sampah, pada observasi ke-8 ada enam orang siswa yang membuang sampah pada tong sampah, pada observasi ke-9 tidak ada siswa yang membuang sampah pada tong sampah, pada observasi ke-10 ada dua orang siswa yang membuang sampah pada tong sampah, pada observasi ke-11 tidak ada siswa yang membuang sampa pada tong sampah dan pada observasi ke-12 ada satu orang siswa yang membuang sampah pada tong sampah. Dari 12 kali observasi yang dilakukan di depan kantin dan kelas IVA \& VIA ada dua puluh empat siswa yang membuang sampah pada tong sampah.

Hasil observasi observasi menunjukkan bahwa sebagian besar siswa yang berada disekitar kantin sudah membuang sampah pada tong sampah, dan sedikit dijumpai siswa yang membuang sampah sembarangan. Hasil yang sama diperoleh dari wawancara, yaitu siswa sudah lebih sering membuang sampah pada tong sampah, namun masih jarang dalam hal mengajak temannya untuk menjaga kebersihan lingkungan, seperti mengajak teman untuk mengutip sampah yang berserakan di halaman sekolah.

Siswa belum sepenuhnya memiliki sikap tanggung jawab terhadap lingkungan, meskipun sekolah sudah berpredikat adiwiyata. Di sekolah Adiwiyata siswa seharusnya sudah bertanggung 
jawab dalam menjaga lingkungan, sesuai dengan tujuan dari program Adiwiyata yaitu: menjadikan sekolah sebagai tempat belajar dan penyadaran warga sekolah akan pentingnya menjaga lingkungan, sehingga warga sekolah terutama siswa dapat turut bertanggung jawab dalam upayaupaya penyelamatan lingkungan hidup di masa yang akan datang (Handayani, Wuryadi, \& Zamroni, 2015; Prasetyo \& Hariyanto, 2017).

\section{b. Solidaritas terhadap Lingkungan}

Solidaritas siswa yang dapat diteliti adalah perilaku siswa yang melarang teman membuang sampah sembarangan. Solidaritas siswa terhadap lingkungan masih belum terlihat, siswa masih belum peduli terhadap lingkungan dengan membiarkan temannya yang membuang sampah sembarangan, persentase sikap solidaritas terhadap lingkungan pada perilaku siswa adalah $0 \%$.

Selama observasi dilakukan ada tidak ada siswa yang merusak tanaman, namun ada tiga orang siswa yang membuang sampah sembarangan. Selama observasi tidak ada terlihat siswa yang melarang temannya yang membuang sampah sembarangan. Selama dilakukannya observasi tidak ada perilaku siswa yang sesuai dengan indikator solidaritas terhadap lingkungan, dari delapan lokasi observasi tidak ada siswa yang melarang temannya untuk tidak membuang sampah atau untuk tidak merusak tanaman.

Berdasarkan hasil observasi yang dilakukan, tidak ada siswa yang melarang temannya yang yang membuang sampah di halaman sekolah, dan dari hasil wawancara yang telah dilakukan, juga diperoleh hasil bahwa siswa juga jarang melarang temannya yang membuang sampah sembarangan, membiarkannya.

\section{c. Kasih Sayang dan Kepedulian terhadap Alam atau Lingkungan}

Siswa tidak memiliki kasih sayang dan kepedulian terhadap alam, tindakan siswa yang menjaga lingkungan sekolah dilakukan karena perintah guru atau karena peraturan, sedangkan dari siswa sendiri tidak ada dijumpai. Aspek yang dilihat dari kasih sayang dan kepedulian terhadap alam atau lingkungan menjaga kebersihan lingkungan secara suka rela seperti mengutip sampah yang berserakan di pekarangan kantin, perilaku ini tidak ada terlihat pada siswa sehingga persentase dari indikator kasih sayang dan kepedulian terhadap alam atau lingkungan adalah $0 \%$.

Pada observasi ke-1, ke-2 dan ke-3 ada sampah yang berserakan disekitar kantin dan kelas, namun siswa yang berada di pekarangan tersebut acuh dan membiarkan sampah tersebut bahkan pada observasi ke-3 ada siswa yang menginjak dan menendang sampah yang berserakan. Pada observasi ke-4 tidak ada sampah yang berserakan disekitar kantin dan kelas, pada observasi ke-5 dan ke-6 siswa membiarkan sampah yang ada disekitar kantin dan kelas, namun pada observasi ke-6 salah seorang siswa mengutip sampah yang berserakan karena peneliti menyuruh siswa tersebut. Pada obserasi ke-7 siswa juga membirakan sampah yang berserakan, dan pada observasi ke-8 salah seorang siswa mengutip sampah yang berserakan karena disuruh oleh peneliti. Pada observasi ke-9, ke10, ke-11 dan ke-12 siswa juga membiarkan sampah yang berserakan disekitar kantin dan kelas, namun pada observasi ke-12 ada salah seorang siswa mengutip sampah karena disuruh oleh peneliti. Selama observasi dilakukan hanya tiga orang siswa yang mengutip sampah karena disuruh, sedangkan siswa yang lain acuh dan tidak peduli terhadap kebersihan lingkungan.

Berdasarkan hasil observasi yang telah dilakukan, siswa kurang peduli terhadap kebersihan lingkungan sekolah. Tidak ada peduli terhadap kebersihan lingkungan, siswa acuh dan membiarkan perkarangan kotor akibat sampah yang berserakan. Sedangkan pada wawancara diperoleh hasil bahwa siswa mengutip sampah yang ada di halaman lebih sering karena disuruh guru.

\section{d. Tidak Merusak Alam atau Lingkungan}

Perilaku siswa yang merusak lingkungan sudah jarang ditemui, meskipun masih ada beberapa siswa yang merusak lingkungan, masih ada dijumpai siswa yang membuang sampah di pekarangan. Siswa dari kantin yang membawa bungkus makanan membuang sampah disekitar pekarangan kantin. Persentase untuk indikator tidak merusak alam atau lingkungan pada perilakuu siswa adalah $50 \%$, karena siswa sudah jarang membuang sampah sembarangan. 
Pada observasi ke-1 ada dua orang siswa yang membuang sampah sembarangan, namun tidak ada siswa yang merusak tanaman yang ada di depan kelas. Pada observasi ke-2 sampai observasi ke-7 tidak ada siswa yang membuang sampah sembarangan ataupun yang merusak tanaman. Pada observasi ke-8 tidak ada siswa yang merusak tanaman, namun ada salah seorang siswa yang membuang sampah disekitar kantin dan kelas. Pada observasi ke-9, ke-10, ke-11dan ke-12 tidak ada siswa yang membuang sampah sembarangan ataupun yang merusak tanaman. Selama observasi dilakukan tidak ada siswa yang merusak tanaman, namun ada tiga orang siswa yang membuang sampah sembarangan.

Berdasarkan hasil observasi, sebagian besar siswa sudah membuang sampah sembarangan. Walaupun demikian, masih ada siswa yang membuang sampah sembarangan.

Wawancara yang dilakukan menunjukkan hasil yang sama, siswa sudah jarang membuang sampah sembarangan.

\section{e. Hidup Sederhana dan Selaras dengan Alam}

Di samping kantin terdapat keran air yang biasanya digunakan oleh siswa. Siswa telah memiliki kesadaran dalam menerapkan hidup sederhana dan selaras dengan alam, meskipun letak keran air jauh dari pengawasan guru siswa tetap menggunakan air secara bijak, persentase indikator hidup sederhna dan selaras dengan alam sudah mencapai $100 \%$.

Selama observasi dilakukan, siswa telah menggunakan air secara bijak. Hasil dari 12 kali dilakukannya observasi menunjukkan hasil yang sama yaitu siswa sudah menggunakan air secara bijak. Adapun yang terlihat selama observasi siswa selalu menutup keran air setelah menggunakannya, tidak ada siswa yang membuang-buang air, dan air digunakan untuk hal yang penting saja seperti untuk mencuci tangan, muka dan lain-lain.

Hasil dari observasi yang telah dilakukan, siswa sudah menerapkan indikator hidup sederhana dan selaras dengan alam. Hal tersebut dilihat dari perilaku siswa ketika menggunakan air, selama observasi dilakukan setiap siswa yang menggunakan air selalu menutup kembali keran air, dan tidak ada terlihat siswa yang membuangbuang air. Hasil dari wawancara yang dilakukan menunjukkan hasil yang sama, siswa selalu menutup keran air setelah menggunakannya dan sudah menggunakan menggunakan air secara bijak dengan tidak membuang-buang air.

Etika lingkungan adalah aturan-aturan atau norma yang dijadikan dan digunakan oleh manusia dalam berperilaku terhadap alam, etika lingkungan sekolah dasar dijadikan atau digunakan oleh warga sekolah dalam berperilaku terhadap lingkungan sekolah. Melalui observasi dan wawacara peneliti mendapatkan data tentang perilaku atau tindakan siswa terhadap lingkungan sekolah terutama disekitar kantin, yang kemudian dilihat berdasarkan indikator etika lingkungan. Gambaran etika lingkungan pada perilaku siswa dapat dilihat pada diagram berikut:

\section{ETIKA LINGKUNGAN DI SD NEGERI 164 PEKANBARU}

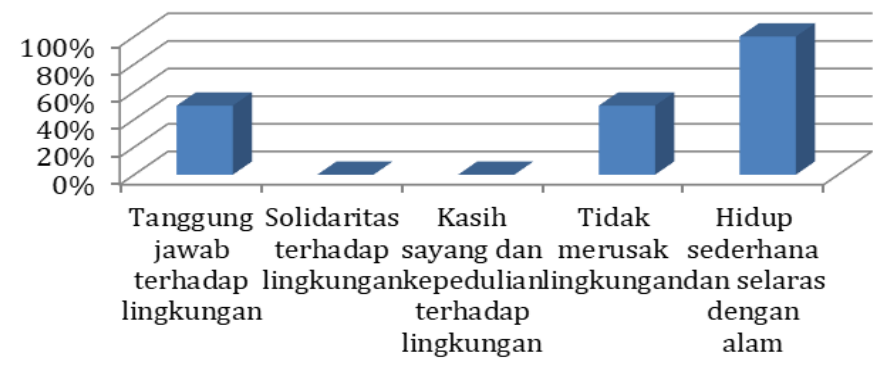

Gambar 1. Persentase Indikator Etika Lingkungan pada Perilaku Siswa 


\section{PRIMARY : JURNAL PENDIDIKAN GURU SEKOLAH DASAR \\ Volume 8 Nomor 2 Oktober 2019 \\ DOI : http://dx.doi.org/10.33578/jpfkip.v8i1.7356 \\ ISSN : 2303-1514 | E-ISSN : 2598-5949 \\ https://primary.ejournal.unri.ac.id/index.php/JPFKIP}

Indikator yang sudah sering terlihat pada perilaku siswa hanya indikator hidup sederhana dan selaras dengan alam dengan persentase $100 \%$, sedangkan indikator tanggung jawab terhadap alam atau lingkungan dan indikator tidak merusak alam tau lingkungan memiliki persentase sebesar $50 \%$, dan indikator hormat terhadap alam atau lingkungan, solidaritas terhadap lingkungan, serta kasih sayang dan kepedulian terhadap lingkungan memiliki persentase $0 \%$.

a. Tanggung jawab terhadap lingkungan
Persentase indikator tanggung jawab yang ada pada peilaku siswa hanya $50 \%$, karena dari 2 aspek yang menggambarkan tanggung jawab terhadap lingkungan tersebut hanya satu yang terlihat pada perilaku siswa. Meskipun siswa sudah sering membuang sampah pada tong sampah, namun masih jarang untuk mengajak temannya dalam menjaga kebersihan lingkungan . Siswa telah memiliki tanggung jawab terhadap sampah yang dimilikinya, namun tanggung jawab siswa terhadap kebersihan lingkungan masih belum terlihat.

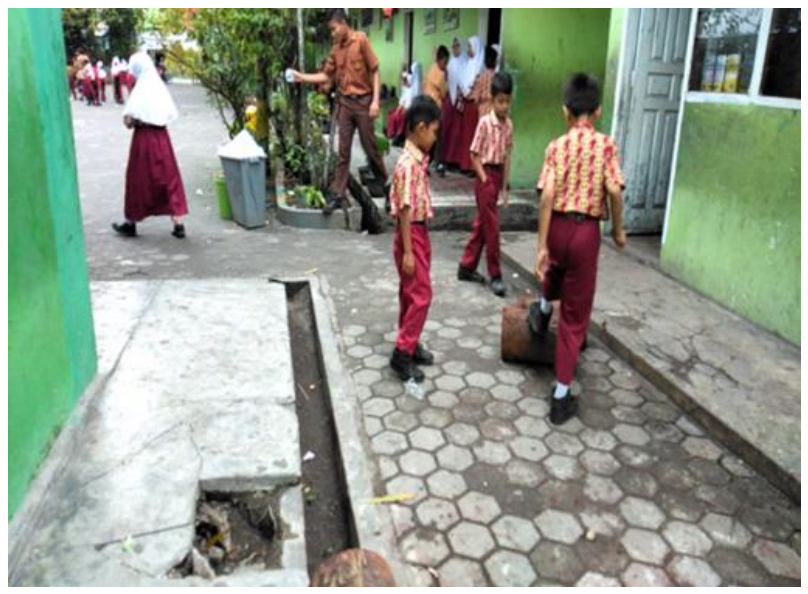

Gambar 2. Siswa yang Membuang Sampah pada Tong Sampah

b. Solidaritas Terhadap Lingkungan

Sikap solidaritas siswa terhadap lingkungan masih belum terlihat, siswa masih belum peduli terhadap lingkungan dengan membiarkan temannya yang merusak lingkungan, persentase sikapsolidaritas terhadap lingkungan pada perilaku siswa adalah $0 \%$.

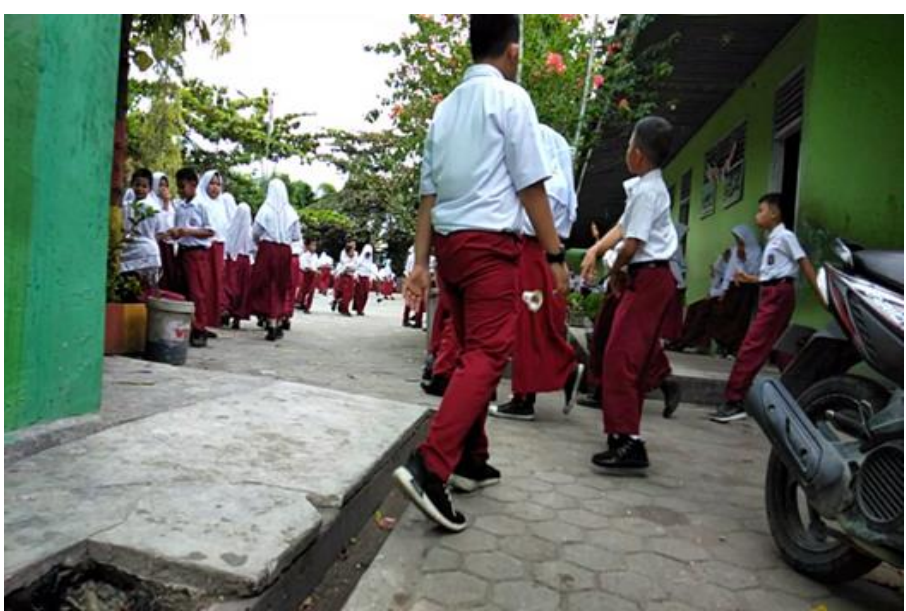

Gambar 3. Tidak Ada Siswa yang Melarang Teman yang Membuang Sampah Sembarangan. 


\section{PRIMARY : JURNAL PENDIDIKAN GURU SEKOLAH DASAR \\ Volume 8 Nomor 2 Oktober 2019 \\ DOI : http://dx.doi.org/10.33578/jpfkip.v8i1.7356 \\ ISSN : 2303-1514 | E-ISSN : 2598-5949 \\ https://primary.ejournal.unri.ac.id/index.php/JPFKIP}

\section{c. Kasih Sayang dan Kepedulian Terhadap Alam atau Lingkungan}

Siswa tidak memiliki kasih sayang dan kepedulian terhadap alam, tindakan siswa yang menjaga lingkungan sekolah dilakukan karena perintah guru atau karena peraturan, sedangkan dari siswa sendiri tidak ada dijumpai. Aspek yang dilihat dari kasih sayang dan kepedulian terhadap alam atau lingkungan adalah merawat tanaman dan menjaga kebersihan lingkungan secara suka rela, kedua perilaku ini tidak ada terlihat pada siswa sehingga persentase dari indikator kasih sayang dan kepedulian terhadap alam atau lingkungan adalah $0 \%$.

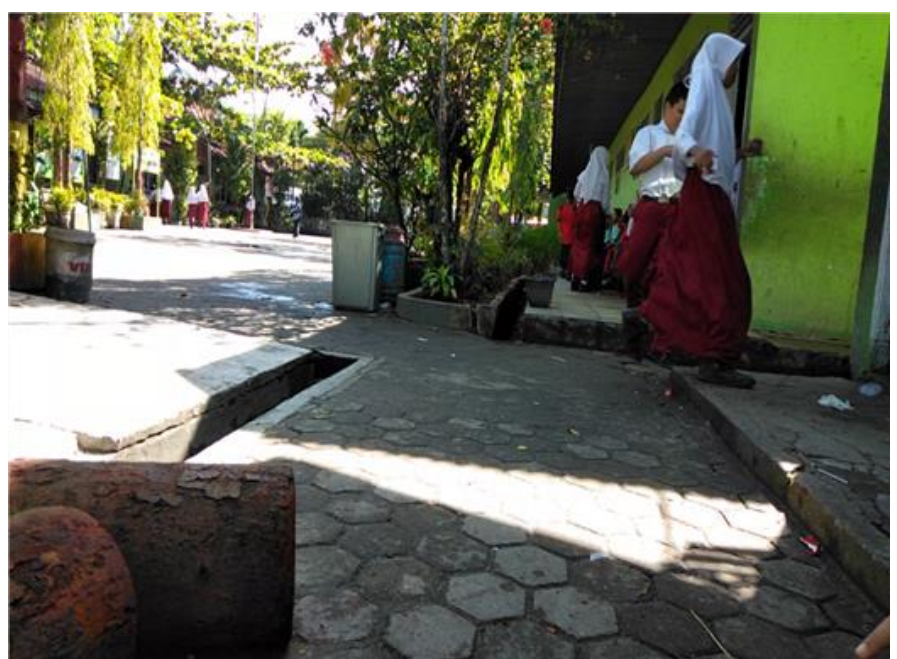

\section{Gambar 4. Siswa Membiarkan Sampah yang Berserakan}

\section{d. Tidak Merusak Alam atau Lingkungan}

Perilaku siswa yang merusak lingkungan sudah jarang ditemui, meskipun masih ada beberapa siswa yang merusak lingkungan, tanaman yang sering dirusak oleh siswa adalah tanaman di depan kelas hal ini karena lokasi tidak selalu terlihat oleh guru. Persentase untuk indikator tidak merusak alam atau lingkungan pada perilakuu siswa adalah 50\%, karena siswa sudah jarang merusak tanaman ataupun membuang sampah sembarangan.

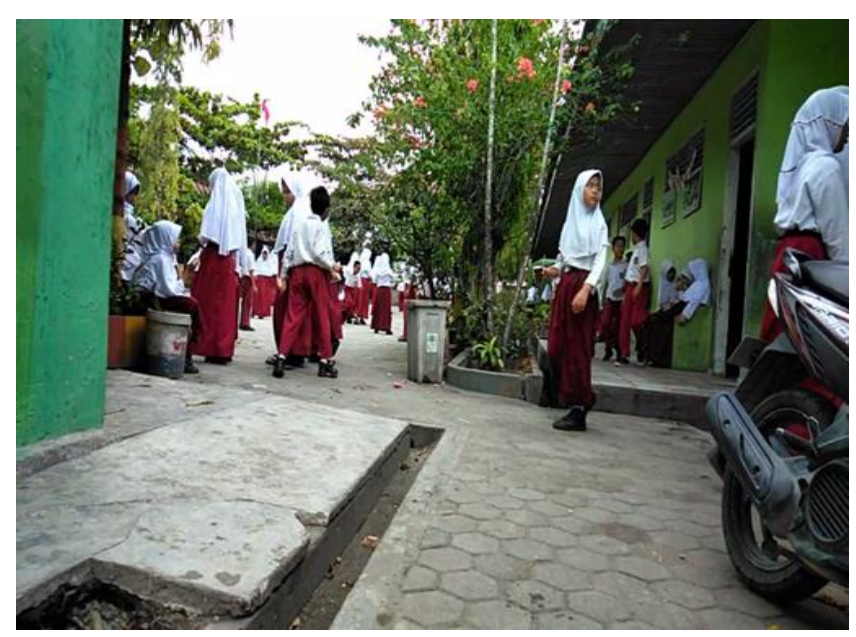

Gambar 4. Siswa Sudah Jarang Merusak Lingkungan 


\section{PRIMARY : JURNAL PENDIDIKAN GURU SEKOLAH DASAR \\ Volume 8 Nomor 2 Oktober 2019 \\ DOI : http://dx.doi.org/10.33578/jpfkip.v8i1.7356 \\ ISSN : 2303-1514 | E-ISSN : 2598-5949 \\ https://primary.ejournal.unri.ac.id/index.php/JPFKIP}

\section{e. Hidup Sederhana dan Selaras dengan Alam}

Siswa telah memiliki kesadaran dalam menerapkan hidup sederhana dan selaras dengan alam, meskipun letak keran air jauh dari pengawasan guru siswa tetap menggunakan air secara bijak, persentase indikator hidup sederhna dan selaras dengan alam sudah mencapai $100 \%$.

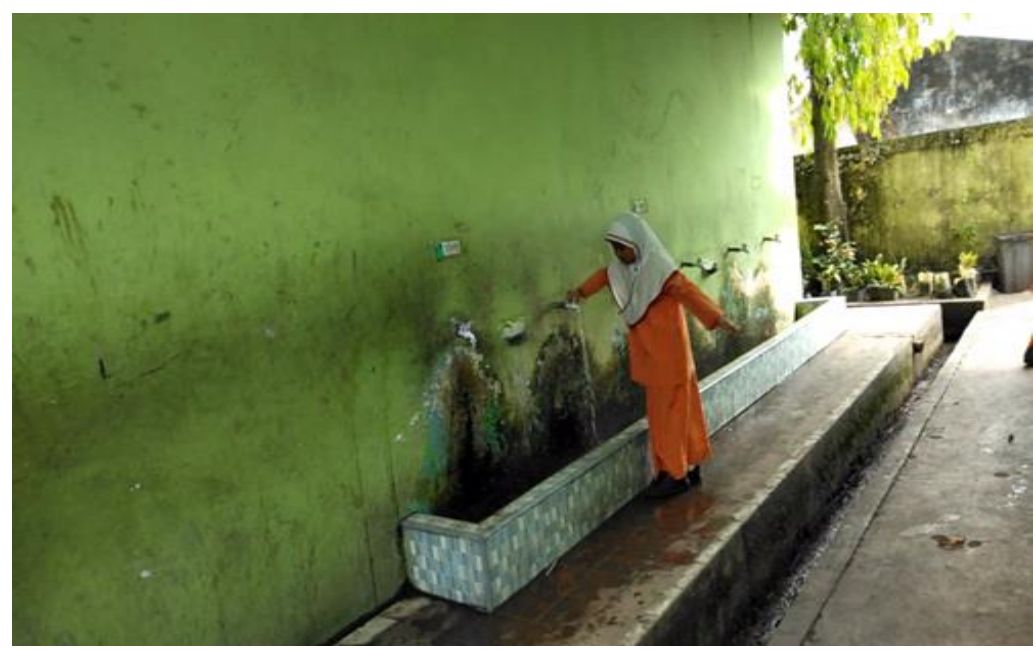

Gambar 6. Siswa Menutup Kembali Keran Air Setelah Menggunakannya

Etika lingkungan adalah aturan-aturan atau norma yang dijadikan dan digunakan oleh manusia dalam berperilaku terhadap alam, etika lingkungan dijadikan atau digunakan oleh warga sekolah dalam berperilaku terhadap lingkungan sekolah. Melalui observasi dan wawacara peneliti mendapatkan data tentang perilaku atau tindakan siswa terhadap lingkungan sekolah, yang kemudian dilihat berdasarkan indikator etika lingkungan. Indikator-indikator etika lingkungan yang ada pada perilaku atau tindakan siswa terhadap lingkungan sudah dapat menggambarkan etika lingkungan yang ada di salah satu sekolah adiwiyata di Pekanbaru.

Etika lingkungan secara keseluruhan masih kurang pada perilaku siswa. Indikator yang sudah sering terlihat pada perilaku siswa hanya indikator hidup sederhana dan selaras dengan alam dengan persentase $100 \%$, sedangkan indikator tanggung jawab terhadap alam atau lingkungan dan indikator tidak merusak alam tau lingkungan memiliki persentase sebesar 50\%, dan indikator hormat terhadap alam atau lingkungan, solidaritas terhadap lingkungan, serta kasih sayang dan kepedulian terhadap lingkungan memiliki persentase $0 \%$. Lima dari indikator yang diteliti, hanya satu indikator yang sudah sering atau selalu diterapkan oleh siwa yaitu indikator hidup sederhana dan selaras dengan alam. Sedangkan indikator yang lain masih belum atau jarang terlihat dalam perilaku siswa terhadap lingkungan. Siswa masih kurang peduli terhadap lingkungan, hal ini dipengaruhi oleh kurangnya etika lingkungan yang dimiliki siswa. Hal tersebut telah dibuktikan dalam penelitian Eko Ariwododo yang meneliti tentang relevansi pengetahuan masyarakat tentang lingkungan dan etika lingkungan dengan partisipasinya dalam pelestarian lingkungan, hasilnya menunjukkan bahwa adanya relevansi antara pengetahuan lingkungan hidup dan etika lingkungan secara bersama sama terhadap partisipasi anggota masyarakat dalam pelestarian lingkungan (Ariwidodo, 2014). Penelitian tentang perilaku lingkungan juga telah diteliti sebelumnya, yaitu meneliti tentang perilaku pelajar tingkat menengah terhadap lingkungan di Kabupaten Bogor. Hasil dari penelitian yang dilakukan, didapatkan hasil bahwa yang paling mempengaruhi perilaku lingkungan adalah norma subjektif. Hal ini selaras dengan teori etika lingkungan (Barkatin et al., 2016).

Sekolah yang mendapat penghargaan Adiwiyata seharusnya memiliki etika lingkungan dalam setiap perilaku warga sekolahnya, karena 
sekolah Adiwiyata adalah tempat yang baik dan ideal dimana dapat diperoleh segala ilmu pengetahuan dan berbagai norma serta etika yang dapat menjadi dasar manusia dalam berperilaku terhadap lingkungan untuk menuju terciptanya kesejahteraan hidup dan menuju kepada cita-cita pembangunan berkelanjutan (Tim Adiwiyata,

\section{SIMPULAN DAN REKOMENDASI}

Berdasarkan penelitian dan hasil analisis data yang telah dilakukan, dapat disimpulkan bahwa etika lingkungan belum sepenuhnya diterapkan oleh siswa disalah satu sekolah adiwiyata di Pekanbaru. Indikator tanggung jawab terhadap lingkungan sudah mulai ada pada siswa, siswa bertanggung jawab terhadap sampah yang dimilikinya yaitu siswa sudah sering membuang sampah pada tong sampah namun masih jarang untuk mengajak temannya dalam menjaga kebersihan lingkungan. Indikator solidaritas terhadap lingkungan belum sepenuhnya ada pada siswa, siswa masih jarang melarang teman yang membuang sampah sembarangan ataupun melarang teman yang merusak tanaman.

Indikator kasih sayang dan kepedulian terhadap alam atau lingkungan belum ada pada siswa, siswa masih jarang dalam hal merawat tanaman dan menjaga kebersihan lingungan sekolah dan siswa melakukannya karena disuruh guru atau pada saat jadwal piket saja. Indikator tidak merusak alam atau lingkungan sudah mulai ada pada diri siswa dalam berperilaku atau bertindak terhadap lingkungan, siswa sudah jarang merusak tanaman dan membuang sampah sembarangan di lingkungan sekolah. Indikator hidup sederhana dan selaras dengan alam sudah ada pada siswa, siswa sudah menggunakan air secara bijak, dengan tidak membuang-buang air dan menutup keran setelah menggunakannya. Enam dari etika lingkungan yang sudah diterapkan oleh siswa adalah indikator hidup sederhana dan

\section{DAFTAR PUSTAKA}

Ariwidodo, E. (2014). Relevansi Pengetahuan Masyarakat Tentang Lingkungan dan Etika Lingkungan dengan Partisipasinya dalam
2012). Namun, berdasarkan data yang diperoleh didapatkan hasil bahwa etika lingkungan masih jarang terlihat dalam perilaku atau tindakan siswa terhadap lingkungan dilihat dari kurangnya penerapan indikator etika lingkungan pada perilaku siswa di lingkungan sekolah.

selaras dengan alam. Sedangkan untuk indikator yang lain masih jarang atau kurang diterapkan oleh siswa di lingkungan sekolah.

Perilaku siswa belum mencerminkan perilaku warga sekolah yang berpredikat adiwiyata, karenamasih kurangnya etika lingkungan yang ada pada perilaku siswa. Sekolah adiwiyata bukan hanya bertujuan menjadikan sekolah yang bersih, namun tujuan dari sekolah adiwiyata adalah mewujudkan warga sekolah yang turut bertanggung jawab terhadap lingkungan. Selain itu warga sekolah terutama siswa seharusnya sudah mengenal atau menerapkan etika lingkungan, karena sekolah adiwiyata adalah tempat diperolehnya segala ilmu pengetahuan dan berbagai norma serta etika yang dapat menjadi dasar manusia dalam berperilaku terhadap lingkungan.

Penulis mengajukan beberapa rekomendasi yaitu: 1) disarankan kepada pihak sekolah agar pihak sekolah agar mengenalkan dan meningkatkan etika lingkungan kepada siswa dalam berperilaku terhadap lingkungan, baik dalam proses pembelajaran maupun diluar pembelajaran, dan menekankan akan pentingnya menjaga lingkungan kepada siswa; 2) disarankan untuk penelitian selanjutnya untuk meneliti kegiatan atau program sekolah yang berhubungan dengan pengenalan dan pembiasaan etika lingkungan pada perilaku siswa; dan 3) Disarankan untuk penelitian selanjutnya untuk meneliti faktor-faktor yang mempengaruhi etika lingkungan pada perilaku siswa di lingkungan sekolah.

Pelestarian Lingkungan. Nuansa, 11(1), 120.

Barkatin, S. L., \& Wijiyanto, H. (2016). Kasus Pendidikan Menengah di Kabupaten 
Bogor. Student Behavior Analysis of Environmental Case Study in Secondary Education Bogor Regency, 6(2), 122-130.

Febrita, E. (2017). Pendidikan Lingkungan. Pekanbaru: CV Draft Media.

Florit, L. F., \& Grava, D.D.S. (2017). Environmental Ethics and Sustainable Territorial Development. an Analysis From the Speciesism Category. Ambiente \& Sociedade, 19(4), 39-58.

Frey, B. S. (1992). Pricing and regulating affect environmental ethics. Environmental \& Resource Economics, 2(4), 399-414.

Handayani, T., Wuryadi, \& Zamroni. (2015). Pembudayaan Nilai Kebangsaan pada Pendidikan Lingkungan Hidup Sekolah Dasar Adiwiyata Mandiri. Jurnal Pemangunan Pendidikan, 3(1), 95-105.

Jennings, V., Yun, J., \& Larson, L. (2016). Finding Common Ground: Environmental Ethics, Social Justice, and a Sustainable Path for Nature-Based Health Promotion. Healthcare, 4(3), 61.

Keraf, A. S. (2010). Etika Lingkungan Hidup (1st ed.). Jakarta: Kompas.

Prasetyo, K., \& Hariyanto. (2017). Pendidikan Lingkungan Indonesia Dasar Pedagogi dan Metodologi. (P. Latipah, Ed.) (1st ed.). Bandung: PT Remaja Rosdakarya.

Riduwan. (2012). Metode \& Teknik Menyusun Proposal Penelitian. Bandung: Alfabeta.

Suliantoro, B. W. (2011). Rekonstruksi Pemikiran Etika Lingkungan Ekofeminisme Sebagai Fondasi Pengelolaan Hutan Lestari. Jurnal Bumi Lestari, 11(1), 111-119.

Tim Adiwiyata. (2012). Panduan Adiwiyata Sekolah Peduli dan Berbudaya Lingkungan. Jakarta: Kementerian Lingkungan Hidup. 